\title{
HYDROCHEMICAL PECULIARITIES OF THE GROUNDWATER COMPOSITION OF THE DUNDRY WATERWAY REGION
}

\author{
${ }^{1}$ Oleynik T.P., PhD., Assistant Professor, \\ tanoley@ukr.net, ORCID: 0000-0002-4469-6797 \\ ${ }^{1}$ Semenova S.V., PhD., Assistant Professor, \\ semenovablacksea@gmail.com, ORCID: 0000-0002-5309-5854 \\ ${ }^{1}$ Makovetskaya E.A., \\ moon.makelen@gmail.com, ORCID: 0000-0002-3135-4333 \\ ${ }^{1}$ Dmitrenko M.P., \\ maryana06@ukr.net, ORCID: 0000-0003-0313-2407 \\ ${ }^{1}$ Odessa State Academy of Civil Engineering and Architecture \\ 4, Didrikhson str., Odessa, 65029, Ukraine
}

\begin{abstract}
The water quality of surface sources of the Odessa region most often does not meet the requirements of regulatory documents, because of the increasing anthropogenic load on the environment, which adversely affects the health of the population. The article analyzes the state of water drinking resources of the Pridunaysky water management district of Ukraine and shows that surface water is not the main source of drinking water supply in the southern regions of the Odessa region. In some large and small settlements located in the Black Sea hydrogeological region, groundwater is the main source of water supply. The main advantage of underground sources when used for drinking water supply is their protection against pollution, bacteriological purity and constancy of the composition. Based on the experimental studies, the quality of the artesian waters of the Izmail was evaluated. The results of the quality assessment allow us to recommend them as sources of drinking water supply. Studies of the chemical composition of water in the centralized drinking water supply in Izmail have shown that the quality of drinking water meets the standards of DSTU 7525:2014 according to the investigated physical and chemical indicators. The hydrochemical composition of the investigated water corresponds to the geological features of the Pridunaysky water management area. It is concluded that there is a need for constant monitoring of the state of underground sources of the Black Sea Artesian Basin, which will allow to use water resources of the region more rationally.
\end{abstract}

Keywords: Black Sea artesian basin, underground water, hydrogeological region, hydrochemical analysis, water quality.

Introduction. Water supply of the southern regions of the Odessa region is carried out both from surface and underground sources. The surface sources are the Danube river and the Danube lakes [1-3]. Due to the increasing anthropogenic impact on the environment, the water quality of surface water bodies does not meet the requirements of regulatory documents. Most surface sources belong to the 3-4 class, i.e. are rated as «slightly contaminated» and «heavily contaminated». According to studies $[4,5]$, the mismatch of surface water quality according to sanitary and microbiological indicators in Izmail city, Kiliya, Reni and Tatarbunary districts reached 13.6-14.7\% for reservoirs of 2nd category and up to $100 \%$ for reservoirs of 1 st category. The results of the analysis of water composition by the content of inorganic nitrogen compounds, which are of biogenic origin, also refer surface water objects to sources of grades 2-4. Pollution of basins with pathogenic microbiota in combination with eutrophication and reproduction of cyanobacteria creates favorable conditions for the propagation of infectious disease pathogens (cholera, legionellosis, leptospirosis, tularemia). Pollution of basins withpathogenic microbiota is confirmed by periodic outbreaks of intestinal infections.

The regional program «Drinking water of Odessa region for 2010-2013 and for the period until 2020» [3] is aimed at solving of existing problems. The tasks of the regional integrated program 
include providing the southern part of the Odessa region (Izmail, Kiliya, Tatarbunary districts) with water of adequate quality to create environmentally safe living conditions for the population.

The inaccessibility of high-quality surface water supply sources and their remoteness from the population necessitates the use of groundwater for drinking needs. The ecological purity of groundwater is their main advantage. The stability of the chemical composition, low content of organic substances, microbiological safety determines the benefits of using underground artesian waters.

Analysis of recent research and publications. Groundwater resources in the regions of Ukraine are unevenly distributed, which is associated with differences in geological, structural and physicalgeographical conditions. On the territory of Ukraine there are 10 hydrogeological regions. Odessa region is located within the Black Sea artesian basin that is least endowed with groundwater reserves due to natural factors: climate factors, geological structure, topography and hydrographic network [6].

An analysis of geomorphological conditions is important for assessing groundwater quality. They determine the patterns of groundwater formation, distribution and regime. In geomorphological terms, the region lies within the borders of the Black Sea lowland (Cretaceous-Cenozoic trench) and its appearance was formed in the Neogene-Quaternary period. The heterogeneity of sediments in the section and frequent alternation caused the formation of a large number of isolated aquifers [7].

The availability of drinking-quality groundwater in the whole Odessa region is $28 \%$ from the explored underground waters of the region, only $9-10 \%$ is used. Groundwater resources throughout the region are extremely unevenly distributed. On the territory of Odessa region, five water management districts are distinguished, which differ greatly in groundwater supply: Northern, Central, Suburban (Trans-Dniester), South-Western, and Danube region. The bulk of the predicted groundwater resources with a mineralization of up to $1.5 \mathrm{~g} / \mathrm{dm}^{3}$ are concentrated in the northern part of the region $[1,2]$.

Within the region, the groundwater regime is formed under the influence of two genetic groups of natural (geological-geomorphological and hydrological) and technogenic factors. In the Black Sea artesian basin, the zone of insufficient moisture with the aquifer complex of the PontMetis-Upper Sarmatian sediments (Neogene aquifer complex) is the most common. Groundwater is contained in rocks of various lithological and facies composition and occur at depths of up to $5 \mathrm{~km}$. Metamorphic and sedimentary rocks of Precambrian, Paleozoic, Mesozoic, and Cenozoic are represented in the Odessa region. According to the literature [2], the aquifers that are exploited in the Odessa region are the Quaternary $(\mathrm{Q})$, Neogene $(\mathrm{N})$, Paleogene $(\mathrm{P})$ and Cretaceous $(\mathrm{K})$ horizons, among which the most powerful aquifers complex of Neogene sediments is the main (84 $\%$ ) (Fig. 1). A change in the mineralization of groundwater of the Neogene complex (from 1.5-3.0 to $94.9 \mathrm{mg} / \mathrm{dm}^{3}$ ) is observed from north to south, towards the sea coast [7-9].

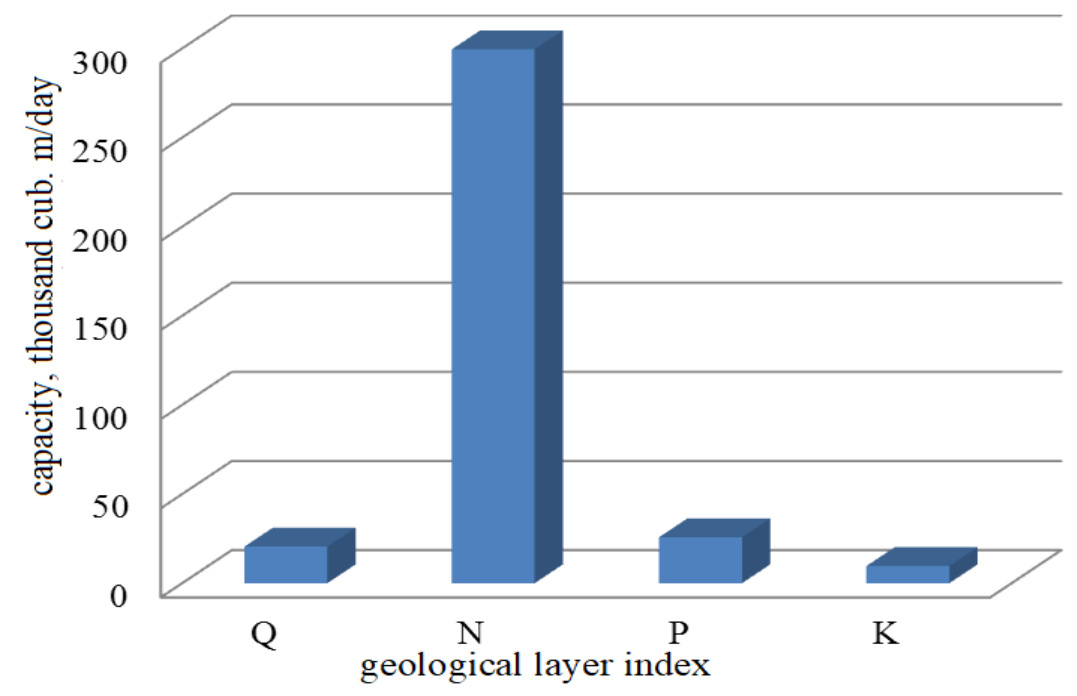

Fig. 1. Histogram of Aquifer Power Quaternary $(\mathrm{Q})$, neogene $(\mathrm{N})$, paleogene $(\mathrm{P})$ и Cretaceous sediments $(\mathrm{K})$ groundwater of Odessa region used for domestic purposes 
The hydrochemical composition of groundwater in Odessa region is formed under the influence of the lithological composition of water-containing layers and depends on the depth. The chemical composition of groundwater in Odessa region is characterized as:

- chloride magnesium-sodium or chloride-sulfate magnesium-sodium (mineralization from 200 to $1000 \mathrm{mg} / \mathrm{m}^{3}$, in some cases up to $2400-5600 \mathrm{mg} / \mathrm{dm}^{3}$ due to the high content of chlorides and sulfates);

- sulfate-chloride magnesium-sodium (mineralization $2200-2400 \mathrm{mg} / \mathrm{dm}^{3}$ - water of the aquifer of Paleogene sediments);

- hydrocarbonate-sulfate with a mixed cationic composition (mineralization of 500-2100 $\mathrm{mg} / \mathrm{dm}^{3}$ - fracture zones of crystalline Precambrian rocks) $[2,8]$.

The underground waters of the Danube water management region (Izmail, Kiliya, Reni districts) are operated by both single wells and group water intakes, as well as numerous wells and springs. 53.7\% of production artesian wells are in unsatisfactory technical condition and require plugging. Such wells are dangerous and can cause pollution of aquifers and emergency epidemiological situations [1,2].

By geographical location, Izmail is located on the left bank of the Danube, $80 \mathrm{~km}$ from the Black Sea in the southwestern part of the Black Sea Lowland (Budzhak plains). By climate, it refers to the southern agro-climatic region of Odessa region (hot, arid, with warm winters), to the plains physical and climatic zone. The region is characterized by a mid-plain subzone, a forestall sod flatland, with low humus southern blacksoil, clays and clay loams of Neogene and Anthropogenic ages.

Despite the abundance of natural surface water bodies around the city of Izmail, the main source of water supply here are artesian wells, the waters of which are distributed in anthropogenic, neogene, and partly in Paleogene and Cretaceous sediments. The Izmail deposit exploits reserves of drinking groundwater of alluvial deposits of the river Danube of the Upper Pliocene and Neopleistocene [1]. By the chemical composition the waters of the Upper Sarmatian sub-tier deposits are sulphatehydrocarbonate, chloride-hydrocarbonate sodium, magnesium-sodium. Mineralization ranges from $0.5-1.5$ to $2.2-3.7 \mathrm{mg} / \mathrm{dm}^{3}$. The waters of the Lower Sarmatian sub-tier sediments are characterized by a diverse composition, they are mainly hydrocarbonate and chloride-hydrocarbonate with a mineralization of $0.4-0.9 \mathrm{mg} / \mathrm{dm}^{3}$ [7].

The design capacity of the approved operational groundwater sources of the Izmail field is 90.2 thousand $\mathrm{m}^{3} /$ day. In fact, the volume of water production is 28.5 thousand $\mathrm{m}^{3} /$ day and consists of 3 group water intakes: «Matroska» (11.6 thousand $\mathrm{m}^{3} /$ day); «Fortress» (12.5 thousand $\mathrm{m}^{3} /$ day); «Canning Factory» (4 thousand $\mathrm{m}^{3} /$ day). The depth of underground wells of existing water intakes is on average $40-70 \mathrm{~m}$.

The study of the hydrochemical composition of groundwater in the deposits of the Izmail region in order to search for additional sources of drinking water will solve the problems of water supply in Izmail and the surrounding villages. The relevance of this work is due to the shortage of quality drinking water in the area.

The purpose and objectives of research. The aim of the work is to assess groundwater sources to ensure rational water supply of the Izmail region. To achieve this goal, it is necessary to solve the following tasks:

- to determine and characterize the hydrochemical composition of the water of artesian wells in the Izmail district of Odessa region;

- assess the quality of drinking water for centralized water supply in Izmail.

Object and subject of research. The objects of research are: water samples of artesian wells No. 1 and No. 20, which are located in the village Matroska area; water from the general water intake of Matroska water intake, which is formed by the underground waters of operating artesian wells. Additional objects of study are water from clean water reservoirs (CVR 1200, CVR 10 000), into which underground waters of all water intakes of the Izmail deposit («Matroska», «Fortress», «Canning Factory») enter; water from the common water supply after the pumping station (PS) for water supply of Izmail. 
The subject of our research is the chemical composition and physical-chemical characteristics of the studied water samples.

Research methods. In these research, the physicochemical methods provided by the relevant regulatory documents were used [10-12]. The main ions (chlorides, calcium, magnesium, hydrocarbonates), total hardness and permanganate oxidation were determined by the titration method; sulfates - by gravimetric method; mineralization was calculated as the sum of the main ions; sodium - by calculation method.

Research results. Table 1 shows the results of research of the composition of groundwater from wells No. 1 and No. 20 and the general water supply of the Matroska water intake.

Table 1 - Composition underground water

\begin{tabular}{|c|c|c|c|c|}
\hline Indicators & Well No. 1 & $\begin{array}{l}\text { Well No. } \\
20\end{array}$ & $\begin{array}{c}\text { General } \\
\text { water supply } \\
\text { t. Matroska }\end{array}$ & $\begin{array}{c}\text { DSanPiN } \\
2.2 .4-171-10 \\
\text { soak well }\end{array}$ \\
\hline $\mathrm{pH}$ & 6.85 & 6.95 & 6.85 & $6.5-8.5$ \\
\hline Color (deg.) & 10 & 10 & 10 & 35 \\
\hline Taste, flavor & 1 & 1 & 1 & 3 \\
\hline Smell (score) & 2 & 2 & 2 & 3 \\
\hline $\mathrm{Na}^{+}$(calculated), $\mathrm{mg} / \mathrm{dm}^{3}$ & 221 & 73 & 65 & 200 \\
\hline $\mathrm{Ca}^{2+}, \mathrm{mg} / \mathrm{dm}^{3}$ & 100 & 62 & 64 & - \\
\hline $\mathrm{Mg}^{2+}, \mathrm{mg} / \mathrm{dm}^{3}$ & 57 & 21 & 26 & - \\
\hline $\mathrm{SO}_{4}{ }^{2-}, \mathrm{mg} / \mathrm{dm}^{3}$ & 280 & 60 & 70 & 500 \\
\hline $\mathrm{Cl}^{-}, \mathrm{mg} / \mathrm{dm}^{3}$ & 283 & 104 & 88 & 350 \\
\hline $\mathrm{HCO}_{3}^{-}, \mathrm{mg} / \mathrm{dm}^{3}$ & 336 & 232 & 256 & - \\
\hline Dry residue (calculated), $\mathrm{mg} / \mathrm{dm}^{3}$ & 1064 & 436 & 441 & 1500 \\
\hline Permanganate oxidation, $\mathrm{mgO} / \mathrm{dm}^{3}$ & 1.04 & 1.52 & 1.28 & $\leq 5$ \\
\hline Total hardness, $\mathrm{mmol} / \mathrm{dm}^{3}$ & 9.7 & 4.8 & 5.3 & 10.0 \\
\hline Mineralization, $\mathrm{mg} / \mathrm{dm}^{3}$ & 1277 & 552 & 569 & - \\
\hline Type of water & brackish & $\begin{array}{l}\text { drinking- } \\
\text { quality }\end{array}$ & $\begin{array}{l}\text { drinking- } \\
\text { quality }\end{array}$ & - \\
\hline
\end{tabular}

Assessment of water composition according to State sanitary rules and regulations (DSanPiN) 2.2.4-171-10 showed that organoleptic and physical-chemical indicators did not exceed permissible norms for underground sources of drinking water. Water from well No. 1 is characterized by a higher mineralization value compared to water from well No. 20 and a common water supply, however, it does not exceed $1500 \mathrm{mg} / \mathrm{dm}^{3}$. This water is brackish and in terms of hardness of 9.7 $\mathrm{mmol} / \mathrm{dm}^{3}$ refers to hard waters. For sodium ions (determined by the calculation method), an excess of the MPC (>200 mg/dm ${ }^{3}$ ) is observed; these data require additional experimental verification. Water from a common water intake of village Matroska, which is sent to underground clean water tanks (CWT), meets the requirements of State sanitary rules and regulations (DSanPiN) 2.2.4-171-10 and State Standards of Ukraine (DSTU)-7525:2014 for centralized water supply. Permanganate oxidation does not exceed the norm $\left(5 \mathrm{mgO} / \mathrm{dm}^{3}\right)$ in all samples, which indicates the absence of contamination with organic substances. No excess of the MAC (maximum allowable concentration) of nitrogen-containing substances was found.

The underground waters of the Sarmatian horizon are characterized by an increased iron content. No iron was found in the samples of the studied water, since analysis to determine the total iron needed to be carried out directly near the source. In air, $\mathrm{Fe}^{2+}$ quickly oxidizes to $\mathrm{Fe}^{3+}$ and precipitates, and this makes the analysis unreliable. Iron belongs to essential trace elements and additional water studies are required to make a final conclusion on the compliance with the DSTU7525:2014 standard for this indicator. 
The hydrochemical classification of natural groundwater is given in Table 2. According to the classification of O. A. Alekin, the water in well No. 1 belongs to the chloride class, sodium group, type II, mineralization $-1.3 \mathrm{~g} / \mathrm{dm}^{3}$, hardness $-10 \mathrm{mEq} / \mathrm{dm}^{3}$; in well No. 20 , water belongs to the hydrocarbonate class, sodium, calcium group, type II, mineralization $-0.6 \mathrm{~g} / \mathrm{dm}^{3}$, hardness -5 $\mathrm{mEq} / \mathrm{dm}^{3}$. Type II waters are formed upon interaction with various sedimentary rocks and bedrock weathering products. This type includes most of the waters of rivers, lakes and ground waters of low and moderate mineralization.

Table 2 - Classification of groundwater

\begin{tabular}{|l|c|c|}
\hline \multirow{2}{*}{ Classification } & \multicolumn{2}{|c|}{ Expression of Result } \\
\cline { 2 - 3 } $\begin{array}{l}\text { Water Index by } \\
\text { Alekin }\end{array}$ & $\mathrm{Cl}_{\mathrm{II}}{ }^{\mathrm{Na} 10}{ }_{1,3}$ & Well No. 20 \\
\hline $\begin{array}{l}\text { Hydrochemical } \\
\text { facies }\end{array}$ & $\mathrm{Na}^{+}-\mathrm{Cl}^{-}-\mathrm{SO}_{4}{ }^{2-}-\mathrm{HCO}_{3}{ }^{-}-\mathrm{Ca}^{2+}-\mathrm{Mg}^{2+}{ }^{2+}$ \\
\hline $\begin{array}{l}\text { Hydrochemical } \\
\text { formation }\end{array}$ & $\mathrm{Na}^{+}$ & $\mathrm{HCO}_{3}{ }^{-}-\mathrm{Na}^{+}-\mathrm{Ca}^{2+}-\mathrm{Cl}^{-}-\mathrm{Mg}^{2+}-\mathrm{SO}_{4}{ }^{2-}$ \\
\hline $\begin{array}{l}\text { The formula of the } \\
\text { salt composition } \\
\text { (Kurlov's formula) }\end{array}$ & $\mathrm{M}_{1,3} \frac{\mathrm{Cl} \cdot 41 \cdot \mathrm{SO}_{4} \cdot 30 \cdot \mathrm{HCO} \cdot 29}{\mathrm{Na} \cdot 50 \cdot \mathrm{Ca} \cdot 26 \cdot \mathrm{Mg} \cdot 24} \mathrm{~T} \cdot 12 \cdot \mathrm{pH} \cdot 6,85$ & $\mathrm{HCO}_{3}{ }^{-}$ \\
\hline
\end{tabular}

According to Kurlov's formula, samples of artesian water from wells are characterized as follows: water from well No. 1 - slightly saline, cold, neutral, chloride-sulfate-hydrogen-carbonate sodium-calcium; water from well No. 20 is fresh, cold, neutral, and hydrocarbonate chloride sodium-calcium.

The hydrochemical characteristics of groundwater by the water index by O.A. Alekin, by the Kurlov formula and by the hydrochemical formation and facies showed that the samples significantly differ in the ratio of the main ions (Fig. 2).

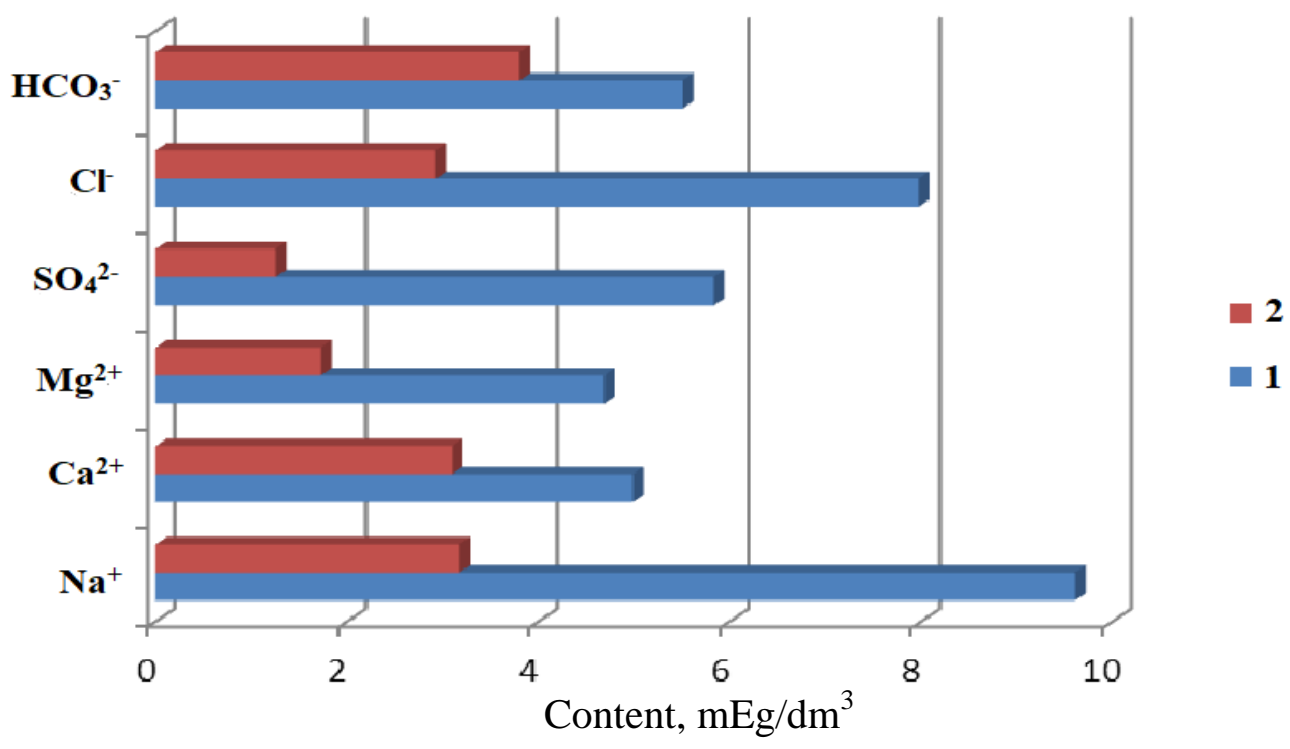

Fig. 2. Histogram of the content of major ions in artesian water: 1 - well No. $1 ; 2$ - well No. 20

Water from the wells is pumped into the common water supply, then it goes into three underground clean water tanks (two small ones - CVR 1200 and one large - CVR 10000, the supplied water flow to three tanks $800 \mathrm{~m}^{3} / \mathrm{h}$ ), then it is disinfected with sodium hypochlorite 
$(\mathrm{NaClO})$ and after comes to the consumer. Additional disinfection of water is carried out with chlorine dioxide once a month, and after rains.

Table 3 shows the results of research of water from clean water tanks (CVR 1200, CVR 10 000). The main source of water supply is water from the CVR 1200. Water from the CVR 10000 is used in small quantities (20\%). The CVR 10000 reservoir has been in operation since 1996 and is subjected to reconstruction due to unsatisfactory condition. Stagnant processes, delayed renewal of the water supply lead to some differences in the composition of the water of the two reservoirs, in particular, for sulfates and sodium. The low concentration of nitrogen-containing substances and the low permanganate oxidation of MHF water indicates the absence of contamination of water with organic substances at the time of sampling. From the research results it follows that according to the studied indicators, the composition of the clean water reservoir corresponds to State Standards of Ukraine (DSTU) 7525:2014.

A water sample from the common water conduit was taken after the pumping station and before being supplied to the consumer. The analysis of the chemical composition of the water from the common water conduit (Table 3) entering the centralized water supply network showed that according to the studied physicochemical parameters, drinking water complies with the standards of State Standards of Ukraine (DSTU) 7525:2014.

Table 3 - Composition of drinking water for centralized water supply

\begin{tabular}{|l|c|c|c|c|}
\hline \multicolumn{1}{|c|}{ Indicators } & CVR 1200 & CVR 10000 & $\begin{array}{c}\text { General } \\
\text { water supply }\end{array}$ & $\begin{array}{c}\text { DSTU25:2014 } \\
7525\end{array}$ \\
\hline $\mathrm{pH}$ & 6.9 & 7.05 & 7.05 & $6.5-8.5$ \\
\hline Color (deg.) & 10 & 10 & 10 & $20(35)$ \\
\hline Taste, flavor & 1 & 1 & 2 & 2 \\
\hline Smell (score) & 2 & 2 & 2 & 2 \\
\hline $\mathrm{Na}^{+}\left(\right.$calculated), mg/dm ${ }^{3}$ & 99 & 155 & 117 & 200 \\
\hline $\mathrm{Ca}^{2+}, \mathrm{mg} / \mathrm{dm}^{3}$ & 68 & 66 & 70 & - \\
\hline $\mathrm{Mg}^{2+}, \mathrm{mg} / \mathrm{dm}^{3}$ & 38 & 36 & 34 & - \\
\hline $\mathrm{SO}_{4}{ }^{2-}, \mathrm{mg} / \mathrm{dm}^{3}$ & 120 & 240 & 155 & $250(500)$ \\
\hline $\mathrm{Cl}^{-}, \mathrm{mg} / \mathrm{dm}^{3}$ & 142 & 133 & 137 & $250(350)$ \\
\hline $\mathrm{HCO}_{3}{ }^{3}, \mathrm{mg} / \mathrm{dm}^{3}$ & 262 & 262 & 262 & - \\
\hline Dry residue (calculated), $\mathrm{mg} / \mathrm{dm}^{3}$ & 598 & 761 & 644 & $1000(1500)$ \\
\hline Permanganate oxidation, $\mathrm{mgO} / \mathrm{dm}^{3}$ & 1.04 & 1.44 & 1.28 & $\leq 5$ \\
\hline Hardness, mmol/dm ${ }^{3}$ & & & & \\
- total & 6.5 & 6.3 & 6.3 & $7(10)$ \\
- carbonate & 4,3 & 4.3 & 4.3 & - \\
- non-carbonate & 2.2 & 2.0 & 2.0 & - \\
\hline
\end{tabular}

The quality of drinking water supplied to the population also depends on the condition of the sources of water intake, their sanitary protection, on the technical condition and equipment of the water supply system. The unsatisfactory technical condition of water supply networks and structures, their deterioration, the elimination of the consequences of accidents and natural disasters creates adverse conditions for the quality of drinking water.

In recent years, due to the use of old equipment, corrosion processes have intensified in water supply networks, which leads to flooding processes and to the appearance of iron in drinking water, i.e. secondary pollution. In the studied drinking water, iron ions were not detected in the dissolved state, however, a light yellow colloidal precipitate was present in the samples. Qualitative analysis with ammonium thiocyanate showed the presence of iron ions. Research in this direction requires clarification. 
Conclusions. Groundwater resources of the Danube water management region are used only by $3-11 \%$. An insufficient level of knowledge and a low degree of development of predicted groundwater resources in the Izmail region reduces the efficiency of their use.

Since geomorphological conditions determine the quality and composition of groundwater, the article analyzes the features of the geological structure and aquifers of the research area.

The results of the study of the hydrochemical composition of groundwater samples from two artesian wells of the Izmail field indicate that the waters differ in the ratio of the main ions and belong to different classes and groups. The waters are characterized as chloride-hydrocarbonate, sodium, calcium, which corresponds to the composition of the aquifer of the Upper Pliocene and Neopleistocene sediments of this water-economic region. Water from wells is of type II, i.e. in accordance with geomorphological conditions, is formed in interaction with various sedimentary rocks and weathering products of bedrock. According to the studied indicators, the quality of water from wells corresponds to State Standards of Ukraine (DSTU) 7525:2014. However, more research is needed to study its composition.

The water quality of the «Matroska» water intake, clean water reservoir and the general water supply system according to the studied physicochemical parameters corresponds to the requirements of regulatory documents for drinking water supply.

In further research, it is recommended to assess the water quality of forecast artesian wells and conduct continuous observation of the status of underground sources of the Danube water management region for the rational use of water resources in this region.

\section{References}

[1] Regionalna dopovid pro stan navkolishnogo prirodnogo seredovischa v Odeskiy oblasti u 2017 rotsi. Odesa, 2018. Available: https://menr.gov.ua/files/docs/Reg.report /2017/Одеса рег.доп.pdf. Accessed on: December 10, 2019).

[2] Stan pidzemnih vod Ukrayini: schorichnik. Kiyiv: Derzhavna sluzhba geologiyi ta nadr Ukrayini, Derzhavne naukovo-virobniche pidpriemstvo: Derzhavniy Informatsiyniy geologichniy fond Ukrayini, 2018.

[3] Odeska oblast. Ekologichniy stan. Problemi vodovidvedennya. Available: http://oblrada.odessa.gov.ua/odeska-oblast/ekologichnij-stan/problemyvodovidvedennya/ Accessed on: March 21, 2019.

[4] M.V. Zaharova, Ya.S. Yarov, "Obzor kachestvennyih harakteristik vodyi byuvetnogo kompleksa g. Odessyi", Visnik Odeskogo derzhavnogo ekologichnogo universitetu, vol. 4, pp. 41-50, 2007.

[5] L.Y. Kovalchuk, "Harakteristika vplivu vodi poverhnevih vodoym Ukrayinskogo Pridunav'ya na zdorov'ya naselennya", Aktualni problemi transportnoyi meditsini, no. 4, t. 2 (42-II), pp. 54-62, 2015.

[6] Priroda Odesskoy oblasti. Resursyi, ih ratsionalnoe ispolzovanie i ohrana / pod red. G.I. Shvebsa, Yu. A.Ambroz. Kiyiv-Odesa: Vischa shkola, 1979. Available: https://collectedpapers.com.ua/ru/the-nature-of-odessa-region/pidzemni-vodiodesko\%d1\%97-oblasti. Accessed on: October 18, 2019.

[7] Stan $i$ yakist prirodnogo seredovischa priberezhnoyi zoni Pivnichno-Zahidnogo Prichornomor'ya: monografiya / za red. T.A. Safranova, A.V. Chugay. Harkiv: FOP Panov A.M., 2017. ISBN 978-617-7541-14-0.

[8] G.I. Rudko i dr., Mediko gidrogeohimicheskie faktoryi geologicheskoy sredyi Ukrainyi. Kiev: Bukrek, 2015.

[9] G.S. Pedan, A.A. Senkovich, "Gidrogeologichni umovi ta osoblivosti formuvannya pidzemnih vod sarmatskogo vodonosnogo gorizontu v pivdenno-zahidniy chastini Odeskoyi oblasti". Visnik ONU. Ser.: Geografichni ta geologichni nauki, T. 20, vol. 2, pp. 170-181, 2015. 
[10] DSTU 4808:2007. Dzherela tsentralizovanogo pitnogo vodopostachannya. Gigienichni ta ekologichni vimogi schodo yakosti vodi i pravila vibirannya. Kiyiv: Derzhspozhivstandart Ukrayini, 2007.

[11] DSanPiN 2.2.4-171-10. Gigienichni vimogi do vodi pitnoyi, priznachenoyi dlya spozhivannya lyudinoyu. Ofitsiyniy visnik Ukrayini, no. 51, pp. 99-129, 2010.

[12] DSTU 7525:2014. Voda pitna. Vimogi ta metodi kontrolyuvannya yakosti. Kiyiv: Minekonomrozvitku Ukrayini, 2014. Available: http://iccwc.org.ua/docs/dstu_7525_2014.pdf Accessed on: November 25, 2019.

\title{
ГІДРОХІМІЧНІ ОСОБЛИВОСТІ СКЛАДУ ПІДЗЕМНИХ ВОД ПРИДУНАЙСЬКОГО ВОДОГОСПОДАРСЬКОГО РАЙОНУ
}

\author{
${ }^{1}$ Олійник Т.П., к.т.н., доцент, \\ tanoley@ukr.net, ORCID: 0000-0002-4469-6797 \\ ${ }^{1}$ Семенова C.B., к.т.н., доцент, \\ semenovablacksea@gmail.com, ORCID: 0000-0002-5309-5854 \\ ${ }^{1}$ Маковецька О.O., \\ moon.makelen@gmail.com, ORCID: 0000-0002-3135-4333 \\ ${ }^{1}$ Дмитренко М.П., \\ maryana06@ukr.net, ORCID: 0000-0003-0313-2407 \\ ${ }^{1}$ Одеська державна академія будівництва та архітектури \\ вул. Дідріхсона, 4, м. Одеса, 65029, Україна
}

\begin{abstract}
Анотація. У зв'язку із зростанням антропогенного навантаження на навколишнє середовище якість води поверхневих джерел Одеської області частіше за все не відповідає вимогам нормативних документів, що несприятливо впливає на здоров'я населення. У статті проаналізовано стан водних питних ресурсів Придунайського водогосподарського району України та показано, що поверхневі води не $\epsilon$ основними джерелами питного водопостачання південних районів Одеської області. У деяких великих і малих населених пунктах, розташованих в Причорноморському гідрогеологічному регіоні, як головні джерела водопостачання, використовуються підземні води. Основною перевагою підземних джерел при використанні для питного водопостачання $\epsilon$ ïх захищеність від забруднень, бактеріологічна чистота і сталість складу. На підставі експериментальних досліджень оцінювалася якість артезіанських вод Ізмаїльського родовища. Результати проведеної оцінки якості дозволяють рекомендувати їх як джерела питного водопостачання. Дослідження хімічного складу води централізованого господарсько-питного водопостачання м.Ізмаїл показали, що якість питної води відповідає нормативам ДСТУ 7525:2014 за дослідженими фізико-хімічними показниками. Гідрохімічний склад досліджуваної артезіанської води відповідає геологічним особливостям Придунайського водогосподарського району. Зроблено висновок про необхідність постійного моніторингу за станом підземних джерел Причорноморського артезіанського басейну, що дозволить більш раціонально використовувати водні ресурси даного регіону.
\end{abstract}

Ключові слова: Причорноморський артезіанський басейн, підземна вода, гідрогеологічний регіон, гідрохімічний аналіз, якість води. 


\title{
ГИДРОХИМИЧЕСКИЕ ОСОБЕННОСТИ СОСТАВА ПОДЗЕМНЫХ ВОД ПРИДУНАЙСКОГО ВОДОХОЗЯЙСТВЕННОГО РАЙОНА
}

\author{
${ }^{1}$ Олейник Т.П., к.т.н., доцент, \\ tanoley@ukr.net, ORCID: 0000-0002-4469-6797 \\ ${ }^{1}$ Семенова С.B., к.т.н., доцент, \\ semenovablacksea@gmail.com, ORCID: 0000-0002-5309-5854 \\ ${ }^{1}$ Маковецкая Е.A., \\ moon.makelen@gmail.com, ORCID: 0000-0002-3135-4333 \\ ${ }^{1}$ Дмитренко М.П., \\ maryana06@ukr.net, ORCID: 0000-0003-0313-2407 \\ ${ }^{1}$ Одесская государственная академия строительства и архитектуры \\ ул. Дидрихсона, 4, г. Одесса, 65029, Украина
}

\begin{abstract}
Аннотация. В связи с ростом антропогенной нагрузки на окружающую среду качество воды поверхностных источников Одесской области чаще всего не соответствует требованиям нормативных документов, неблагоприятно влияет на здоровье населения. В статье проанализировано состояние водных питьевых ресурсов Придунайского водохозяйственного района Украины и показано, что поверхностные воды не являются основными источниками питьевого водоснабжения южных районов Одесской области. В некоторых больших и малых населенных пунктах, расположенных в Причерноморском гидрогеологическом регионе, в качестве основных источников водоснабжения используются подземные воды. Основным преимуществом подземных источников при использовании для питьевого водоснабжения является их защищенность от загрязнений, бактериологическая чистота и постоянство состава. На основании экспериментальных исследований оценивалось качество артезианских вод Измаильского месторождения. Результаты проведенной оценки качества позволяют рекомендовать их как источник питьевого водоснабжения. Исследование химического состава воды централизованного хозяйственно-питьевого водоснабжения г. Измаил показали, что качество питьевой воды соответствует нормативам ДСТУ 7525:2014 по исследованным физико-химическим показателям. Гидрохимический состав исследуемой артезианской воды соответствует геологическим особенностям Придунайского водохозяйственного района. Сделан вывод о необходимости постоянного мониторинга за состоянием подземных источников Причерноморского артезианского бассейна, что позволит более рационально использовать водные ресурсы данного региона.
\end{abstract}

Ключевые слова: Причерноморский артезианский бассейн, подземная вода, гидрогеологический регион, гидрохимический анализ, качество воды.

Стаття надійшла до редакції 04.02.2020 